\title{
Pengembangan Formulasi Pasta Antiinflamasi Piroksikam Berbasis Ampas Tahu dalam Pemanfaatan Limbah Tahu Di Purwokerto
}

\section{(Formulation of Piroksikam Anti-Inflamation Paste from Soybean Curd Residue in Utilization Soybean Waste at Purwokerto)}

\author{
NITA TRIANA SARI*, PUTRI DEWI RIAYAH, NABILA FASYA, AINUL MARDZIYATI A, \\ NAMIRA FADHILAH B, NURYANTI
}

Jurusan Farmasi Fakultas Ilmu-IImu Kesehatan Universitas Jenderal Soedirman

Diterima 5 Juni 2017, Disetujui 14 Agustus 2017

\begin{abstract}
Abstrak: Ampas tahu adalah residu hasil perasan kedelai yang mengandung karbohidrat tinggi sehingga berpotensi untuk diolah menjadi eksipien dalam sediaan farmasi.Penelitian ini bertujuan untuk mengevaluasi kemampuan ampas tahu sebagai eksipien pada sediaan farmasi pasta antiinflamasi piroksikam. Eksipien pati ampas tahu dibuat dengan cara diisolasi menggunakan $\mathrm{KOH} \mathrm{0,1 \% ,} \mathrm{kemudian}$ dikarakterikasi sifat fisika, kimia, dan fungsional setelah menjadi tahu. Pati ampas tahu selanjutnya dibuat sediaan pasta antiinflamasi piroksikam dengan perbandingan pati ampas tahu dan amilum manihot F1 (0:0,25), F2 (0,25:0), F3 (1,25:1,25), F4 (1,5:1), F5 (1:1,5). Hasil uji sifat fisik dan uji stabilitas Freeze-thaw dianalisis secara deskriptif. Hasil uji viskositas, daya lekat, dan daya sebar dianalisis menggunakan one way ANOVA. Hasil karakterisasi fisik pati ampas tahu berupa serbuk sedikit kasar, berbentuk batang, permukaan tidak rata dan tidak berpori, sedikit higroskopis, berwarna putih kecoklatan, memiliki bau yang khas, dan tidak memiliki rasa. Hasil karakterisasi kimia menunjukkan bahwa pati ampas tahu mengandung karbohidrat dan memiliki pH 4,9. Hasil karakterisasi fungsional pati ampas tahu memiliki viskositas 1959 cps (15\%), waktu alir 6,7 detik dan sudut diam ( $\alpha$ ) 39,20. Hasil uji sifat fisik dan stabilitas menunjukkan bahwa F3 sebagai formula pasta antiinflamasi piroksikam terbaik.
\end{abstract}

Kata kunci: ampas tahu, eksipien, pasta piroksikam.

\begin{abstract}
The soybean curd residue is the waste product of soybean. It has potential for being excipients in pharmaceutical preparations because of its high carbohydrate element. This study aims to evaluate the soybean curd residue as excipients of piroxicam antiinflammatory paste. The excipient of soybean curd residue is made by isolating it with $0.1 \% \mathrm{KOH}$, then being characterized by physical, chemical, and functional test after becoming starch. It was prepared in piroxicam antiinflammatory paste preparations with ratio of soybean curd residue starch and manihot strach are F1 (0:0.25), F2 $(0.25: 0)$, F3 (1.25:1.25), F4 (1.5:1), and F5 (1:1.5). The result of physical and freeze-thaw stability test were analyzed descriptively. The data of viscosity, stickiness, and spreading power test were analyzed using one-way ANOVA. Soybean curd residue starch's physic is slightly coarse, cubic-shapes powder, uneven surface and non-porous, slightly hygroscopic, and brownish-white. It has distinctive odor and has no taste. Chemical test showed that it contained carbohydrate and had $\mathrm{pH} 4.9$. Functional test showed on average $15 \%$ it has viscosity $1959 \mathrm{cps}$, flow time 6.7 seconds and still angle 39.20 . Results of physical and stability tests showed that F3 were the best piroxicam antiinflammatory paste formula.
\end{abstract}

Keywords: soybean curd residue, excipient, piroxicam paste.

*Penulis korespondensi: Hp : 085742282802

Email: nitatrianasari@yahoo.co.id 


\section{PENDAHULUAN}

INDONESIA merupakan negara dengan pasar farmasi berkisar 43 triliun rupiah yang memiliki market value untuk bahan baku obat berkisar 14 triliun rupiah. Bahan baku yang digunakan tersebut sekitar 96\% merupakan bahan baku impor ${ }^{(1)}$. Hal ini menunjukkan bahwa Indonesia masih sangat bergantung terhadap bahan baku impor dan belum memanfaatkan potensipotensi yang dimiliki. Bahan baku yang berpotensi untuk dikembangkan di Indonesia adalah pati. Pati merupakan polisakarida yang tersusun dari sejumlah molekul monosakarida. Pati secara luas digunakan dalam industri farmasi sebagai eksipien seperti pengikat, desintegran dan pengisi ${ }^{(2)}$.

Salah satu bahan yang berpotensi untuk diolah menjadi pati adalah ampas tahu. Ampas tahu merupakan residu hasil perasan kedelai yang selama ini nyaris tidak dimanfaatkan kecuali sebagai pakan ternak dan bahan makanan ${ }^{(3)}$. Kandungan karbohidrat yang tinggi memungkinkan ampas tahu dapat diolah menjadi pati, sehingga dapat digunakan sebagai eksipien dalam sediaan farmasi. Beberapa penelitian menggunakan pati ampas tahu sebagai eksipien dalam formulasi tablet sudah dilakukan.

Hasil penelitian Mufrod dan Sundari (1997) menunjukkan bahwa ampas tahu diketahui memiliki sifat yang mudah menyerap air sehingga dapat digunakan sebagai disintegran dalam sediaan tablet parasetamol ${ }^{(4)}$. Penelitian tersebut sesuai dengan Fressia (2000) yang meneliti tentang penggunaan ampas tahu kering sebagai disintegran pada tablet parasetamol dengan metode granulasi basah ${ }^{(5)}$. Utami (2000) meneliti tentang uji kelayakan ampas tahu kering sebagai disintegran tablet hisap vitamin $\mathrm{C}^{(6)}$. Namun demikian penelitian tentang karakteristik dan penggunaan ampas tahu pada sediaan semisolid terutama pasta belum ditemukan.

Pasta merupakan sediaan semisolid yang terdiri dari 50\% bahan padat, sehingga memiliki keuntungan dapat mengikat cairan eksudat, daya lekatnya lebih kuat dari sediaan salep dan dapat memberikan lapisan tipis (film) untuk melindungi kulit atau jaringan di bawahnya $^{(7)}$. Salah satu bahan aktif yang dapat dibuat menjadi sediaan pasta adalah piroksikam. Piroksikam adalah obat anti inflamasi non-steroid yang berfungsi meredakan rasa sakit tingkat ringan hingga menengah.

Obat ini sering digunakan untuk mengurangi gejala-gejala artritis, seperti inflamasi, pembengkakan, serta kaku dan nyeri otot ${ }^{(8)}$. Sediaan piroksikam yang sudah beredar di pasaran adalah dalam bentuk tablet, kapsul dan gel. Sehingga masih dapat dikembangkan sediaan antiinflamasi topikal piroksikam dalam bentuk sediaan pasta. Penelitian ini bertujuan untuk mengevaluasi karakteristik fisik, kimia dan fungsional pati ampas tahu serta membuat sediaan pasta antiinflamasi piroksikam yang memenuhi syarat sifat fisik dan stabilitas fisik dengan menggunakan basis pati ampas tahu.

\section{BAHAN DAN METODE}

BAHAN. Bahan utama yang digunakan adalah ampas tahu yang diperoleh dari pengrajin tahu di daerah Kaliputih Purwokerto. Bahan lain yang digunakan adalah phosphate buffer $\mathrm{pH} 4$, kalium hidroksida, aquades, alkohol, pereaksi iodin, vaselin flavum, amilum manihot, zink oksida, dan piroksikam.

METODE. Isolasi Pati dari Ampas Tahu. Isolasi pati dari ampas tahu dilakukan dengan cara pengeringan ampas tahu hingga menjadi serbuk. Sebanyak 200 gram serbuk ditimbang kemudian

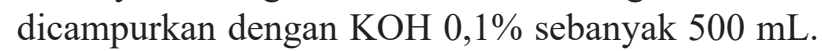
Kemudian diaduk dengan magnetik stirer selama 20 menit dan didiamkan selama 24 jam di lemari pendingin. Supernatan kemudian didekantasi, dan fase padatnya ditambahkan $\mathrm{KOH} 0,1 \%$ kembali dan diaduk 20 menit. Penambahan $\mathrm{KOH}$ direplikasi 3 kali. Fase padat kemudian ditambahkan aquades dan didiamkan 20 menit. Supernatan yang tebentuk didekantasi dan fase padat ditambahkan air suling lagi. Prosedur dilakukan 3 kali pengulangan. Residu pati dikumpulkan, divakum, dikeringkan dan ditampung.

Karakterisasi Fisik Pati Ampas Tahu. Penampilan Sifat Fisik. Pati ampas tahu yang diperoleh dari isolasi diamati dan dicatat bentuk, warna, bau dan rasa ${ }^{(9)}$.

Morfologi Partikel. Morfologi partikel pati ampas tahu diamati dengan scanning electron microscope (SEM). Sampel ditempelkan pada holder dengan menggunakan carbone tape, kemudian dimasukkan ke dalam coating unit untuk dilapisi dengan logam emas $(\mathrm{Au})$. Holder kemudian dimasukkan kedalam SEM kemudian diamati dengan beberapa perbesaran

Distribusi Ukuran Partikel. Pengayak ditimbang dahulu kemudian disusun mulai dari atas yaitu ayakan dengan mesh 40, 45, 100, dan 120. Sejumlah 51,77 gram serbuk pati ampas tahu dimasukkan pada pengayak dengan mesh terkecil kemudian pengayakan dliakukan secara manual selama 20 menit. Serbuk pati yang lolos pada setiap ayakan ditimbang dan dihitung persentase berat serbuk pati yang lolos. Hasil ini mengintepretasikan sifat kekasaran serbuk pati ampas tahu.

Higroskopisitas. Sampel ditimbang 1 gram. Kemudian di tempatkan pada pot plastik dengan 2 perlakuan yaitu pot plastik tanpa tutup dan pot plastik dengan tutup. Masing-masing pot diletakkan 
di ruang terbuka. Sampel diamati setiap hari terhadap karakteristik fisik meliputi perubahan warna dan masanya selama 7 hari.

Karakterisasi Kimia Pati Ampas Tahu. Identifikasi Pati Ampas Tahu. Sebanyak 1,02 gram pati ampas tahu yang diperoleh dipanaskan hingga mendidih selama satu menit dalam $50 \mathrm{~mL}$ aquades. Kemudian didinginkan. Lalu sebanyak $1 \mathrm{~mL}$ larutan tersebut dicampur dengan iodium dan akan terbentuk warna biru tua atau ungu yang hilang pada pemanasan dan timbul kembali pada pendinginan.

Pengukuran pH. Sampel ditimbang sebanyak 4,89 gram kemudian dicampur dengan $25 \mathrm{~mL}$ aquades. Selanjutnya diaduk selama 5 menit dan didiamkan 10 menit, dan diukur dengan $\mathrm{pH}$ meter. Setelah $\mathrm{pH}$ meter dikalibrasi menggunakan buffer $\mathrm{pH} 4, \mathrm{pH}$ meter dicelupkan ke dalam larutan tersebut dan didiamkan hingga didapat $\mathrm{pH}$ konstan ${ }^{(10)}$.

Karakterisasi Fungsional Pati Ampas Tahu. Pengukuran Viskositas Pati Ampas Tahu. Pengukuran viskositas dilakukan dengan mendispersikan pati ampas tahu kedalam aquades dengan konsentrasi $15 \% \mathrm{~b} / \mathrm{v}$ dalam aquades, kemudian viskositas diukur dengan viskometer Brookfield.

Pemeriksaan Sifat Alir. Pemeriksaan sifat alir dilakukan dengan cara sebanyak 81,5 gram pati ampas tahu dimasukkan kedalam corong yang ujung tangkainya ditutup. Penutup corong dibuka dan pati ampas tahu dibiarkan mengalir hingga habis. Lalu dihitung waktu alir dan sudut diamnya $(\alpha)^{(11)}$.

Pembuatan Pasta Piroksikam. Pasta piroksikam dibuat sesuai dengan komposisi bahan pada Tabel 1 .

Tabel 1. Formula pasta piroksikam.

\begin{tabular}{|c|c|c|c|c|c|}
\hline Formula & Ampas Tahu (g) & Amilum Intitic $(\mathrm{g})$ & Zinc Oxydun (g) & Piroxicam(mg) & Vassin Alarum (g) \\
\hline $\mathrm{Fl}$ & 0 & 2,5 & 2,5 & 20 & Ad 10 \\
\hline $\mathrm{F} 2$ & 2,5 & 0 & 2,5 & 20 & Ad10 \\
\hline $\mathrm{F} 3$ & 1,25 & 1,25 & 2,5 & 20 & Ad10 \\
\hline F4 & 1,5 & 1 & 2,5 & 20 & Ad10 \\
\hline F5 & 1 & 1,5 & 2,5 & 20 & Ad10 \\
\hline
\end{tabular}

Pembuatan pasta dilakukan dengan cara melelehkan vaselin flavum kemudian dicampurkan dengan piroksikam. Selanjutnya campur dengan zink oksida yang telah diayak dengan ayakan nomor 100 . Ditambahkan amilum manihot dan atau pati ampas tahu. Kemudian semua bahan dicampur hingga homogen.

Evaluasi Sediaan Pasta Piroksikam (Uji Sifat Fisik). Uji sifat fisik sediaan pasta dilakukan pada sediaan yang disimpan pada suhu ruang $27,2{ }^{\circ} \mathrm{C}$ dan kelembaban $65 \%$. Uji sifat fisik dilakukan dengan replikasi 3 kali pada hari ke-1, 3, 5, 7, 14, 21, dan 28 .
Uji sifat fisik sediaan meliputi:

Uji Organoleptis. Uji organoleptis dilakukan dengan mengamati bentuk, warna dan bau sediaan pasta piroksikam ${ }^{(12)}$.

Pengukuran pH. Pengukuran $\mathrm{pH}$ dilakukan dengan cara mencelupkan strip indikator unversal kedalam sediaan pasta piroksikam kemudian diamati perubahan warna pada strip indikator ${ }^{(10)}$.

Uji Viskositas. Sebanyak 100 gram sediaan pasta diuji viskositas menggunakan viskositas Brookfield. Celupkan spindle nomor 64 ke dalam sediaan pasta dan atur kecepatan $5 \mathrm{rpm}$ kemudian diamati viskositas sediaan pada monitor alat ${ }^{(13)}$. Data hasil semua formula dilakukan masing-masing uji analisis berupa homogenitas menggunakan SPSS 17. Apabila didapat data yang homogen dilanjutkan dengan uji analisis one way ANOVA untuk mengetahui ada tidaknya perbedaan hasil dalam semua formula. Uji analisis ini menggunakan $\alpha=0,05$.

Uji Daya Sebar. Sebanyak 0,5 gram pasta diletakkan di tengah petri kemudian petri yang satu diletakkan di atasnya dibiarkan selama satu menit. Diameter pasta yang menyebar diukur dengan menggunakan penggaris, kemudian ditambahkan 50 gram beban tambahan dan didiamkan satu menit, lalu diukur diameter pasta yang menyebar ${ }^{(13)}$. Data hasil semua formula dilakukan masing-masing uji analisis berupa homogenitas menggunakan SPSS 17. Apabila didapat data yang homogen dilanjutkan dengan uji analisis one way ANOVA untuk mengetahui ada tidaknya perbedaan hasil dalam semua formula. $\mathrm{Uji}$ analisis ini menggunakan $\alpha=0,05$.

Uji Daya Lekat. Pasta sebanyak 0,3 gram diletakkan diatas objek gelas yang telah ditentukan luasnya. Objek gelas yang berisi pasta ditempelkan ke obek gelas yang lain kemudian ditekan dengan beban $1 \mathrm{~kg}$ selama 5 menit. Objek gelas dipasang pada alat tes dan dilepaskan beban seberat 80 gram. Waktu yang diperlukan hingga dua objek gelas tersebut terlepas dicatat ${ }^{(13)}$. Data hasil semua formula dilakukan masing-masing uji analisis berupa homogenitas menggunakan SPSS 17. Apabila didapat data yang homogen dilanjutkan dengan uji analisis one way ANOVA untuk mengetahui ada tidaknya perbedaan hasil dalam semua formula. Uji analisis ini menggunakan $\alpha=0,05$.

Uji Stabilitas. Sediaan pasta piroksikam diuji dengan metode Freeze-Thaw dengan cara disimpan didalam ruangan bersuhu dingin $\left(4^{\circ} \mathrm{C}\right)$ selama 48 jam dilanjutkan dengan penyimpanan dalam oven (suhu $40{ }^{\circ} \mathrm{C}$ ) selama 48 jam yang merupakan 1 kali siklus. Cara ini dilakukan secara berulang sebanyak 6 kali siklus dan diamati apakah terjadi pemisahan dua fase. 


\section{HASIL DAN PEMBAHASAN}

Hasil Isolasi Pati dari Ampas Tahu. Isolasi $5 \mathrm{~kg}$ ampas tahu menghasilkan pati ampas tahu sebesar 2 $\mathrm{kg}$. Hasil karakterisasi pati ampas tahu:

Karakterisasi Fisik. Penampilan Sifat Fisik. Hasil pengamatan penampilan fisik menunjukkan bahwa pati ampas tahu berupa serbuk berwarna putih kecoklatan (krem), memiliki bau yang khas, dan tidak memiliki rasa (Gambar 1).

Morfologi Partikel. Hasil pengamatan morfologi partikel menggunakan Scanning Electron Microscope (SEM) dengan perbesaran 100x, 500x, 1000x, 2000x, 3000x, dan 4000x menunjukkan bahwa partikel pati ampas tahu berbentuk batang, permukaan tidak rata, dan tidak berpori (Gambar 2).

Distribusi Ukuran Partikel. Berdasarkan hasil uji distribusi ukuran partikel (Tabel 2) diketahui bahwa pati ampas tahu sebanyak $91,4 \%$ lolos pada ayakan 40 mesh. Oleh karena itu, pati ampas tahu digolongkan sebagai serbuk yang sedikit kasar ${ }^{(14)}$.

Higroskopisitas. Hasil uji higrokopisitas (Tabel 3) menunjukkan bahwa pati ampas tahu dalam kondisi tertutup tidak mengalami perubahan warna dan bentuk selama perlakuan. Sedangkan pati ampas tahu dalam wadah tanpa tutup tidak menunjukkan perubahan warna dan bentuk tetapi menunjukkan penambahan massa. Dapat disimpulkan pati ampas tahu merupakan bahan yang sedikit higroskopis maka dari itu penyimpanan pati sebaiknya dalam wadah tertutup rapat ${ }^{(15)}$.

Karakterisasi Kimia. Identifikasi Ampas Tahu. Hasil identifikasi karbohidrat dalam pati ampas tahu menunjukkan positif adanya karbohidrat. Hal ini ditandai dengan perubahan warna menjadi merah kecoklatan setelah ditetesi Iodin. Kemudian didapat uap ungu setelah dilakukan pemanasan (Gambar 3) dikarenakan pati mengandung amilopektin lebih banyak dibanding amilosa ${ }^{(16)}$.

Pengukuran pH. Hasil pengukuran $\mathrm{pH}$ pati ampas tahu dengan indikator universal (Gambar 4) menunjukkan bahwa pati ampas tahu memiliki $\mathrm{pH}$ 4,9 yang menandakan bersifat asam ${ }^{(2)}$.

Karakterisasi Fungsional. Pengukuran Viskositas Pati Ampas Tahu. Hasil uji viskositas terhadap konsentrasi $15 \%$ pati ampas tahu menunjukkan bahwa pati ampas tahu memiliki viskositas $1.959 \mathrm{cps}$.

Pemeriksaan Sifat Alir. Hasil uji sifat alir serbuk pati ampas tahu diketahui bahwa waktu alir 6,7 detik dan sudut diam $(\alpha)$ sebesar $39,2^{\circ}$. Pati ampas tahu memiliki sifat alir yang baik karena mempunyai waktu alir tidak lebih dari 10 detik dan sudut diam $20-40^{\circ}(17)$.

Hasil Evaluasi Sediaan Pasta Piroksikam. Uji Sifat Fisik. Uji organoleptis. Hasil uji organoleptis

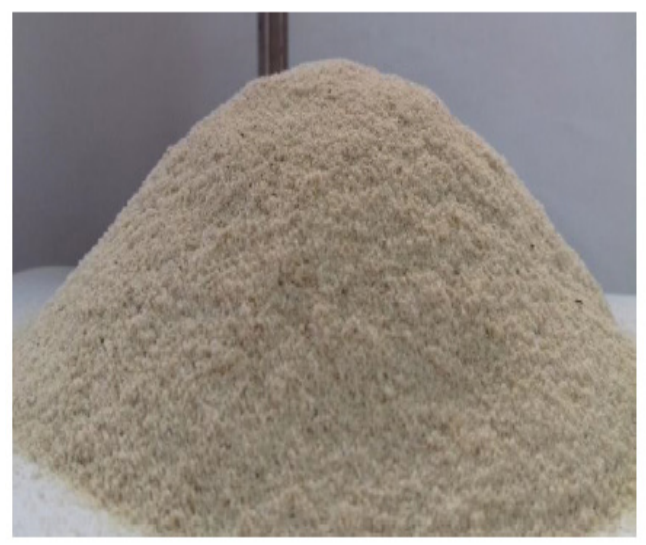

Gambar 1. Pati ampas tahu.
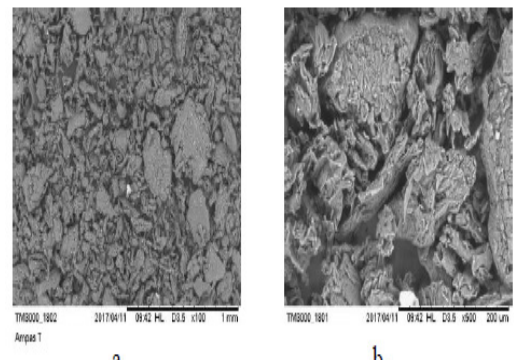

b.
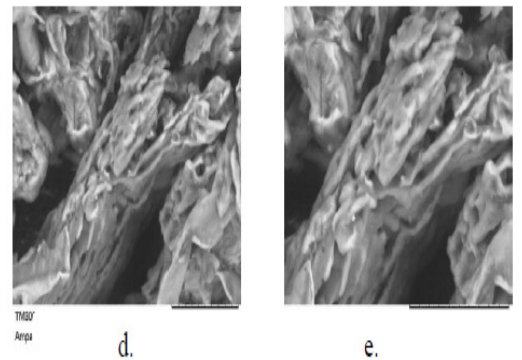

e.
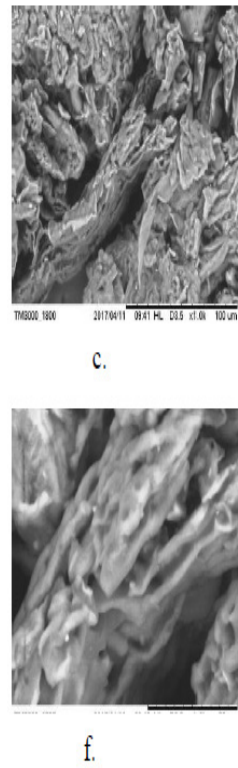

f.
Gambar 2. Morfologi partikel pati ampas tahu menggunakan SEM perbesaran (a) 100x; (b) 500x; (c)1000x; (d) 2000x; (e) 3000x dan (f) 4000x.

Tabel 2. Hasil distribusi partikel pati ampas tahu.

\begin{tabular}{|c|c|c|c|c|}
\hline & \multicolumn{4}{|c|}{ Distribusis Thuran Partike (\%) } \\
\hline & Lolos Mest 120 & Lolos Mesh 100 & Lolos Mess 45 & Lolos Mesh 40 \\
\hline PatiAmpis Tatu & 1,4 & 14 & 86,4 & 91,4 \\
\hline
\end{tabular}

Tabel 3. Hasil uji higroskopisitas pati ampas tahu.

\begin{tabular}{ccc}
\hline Hari Ke- & Bobot Patid dengan Tutup (gr) & Bobot Pati Tanpa Tutup (gr) \\
\hline 1 & 7,260 & 5,737 \\
2 & 7,270 & 5,740 \\
3 & 7,273 & 5,757 \\
4 & 7,274 & 5,766 \\
5 & 7,189 & 5,773 \\
6 & 7,199 & 5,779 \\
7 & 7,198 & 5,783 \\
\hline
\end{tabular}




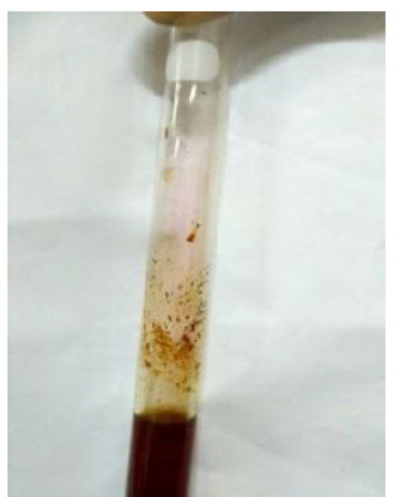

Gambar 3. Identifikasi karbohidrat dalam pati ampas tahu.

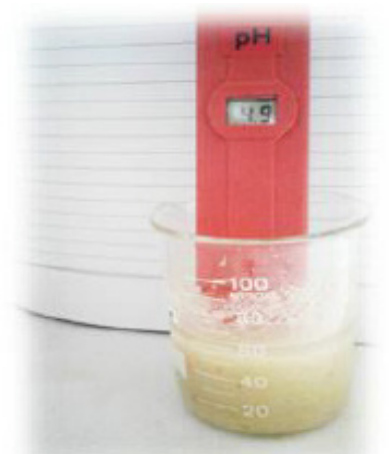

Gambar 4. Hasil pengujian pH pati ampas tahu.

sediaan pasta piroksikam menunjukkan bahwa F1 dan F2 memiliki bentuk yang lebih padat dibandingkan dengan F3, F4 dan F5. Hal ini disebabkan karena F1 hanya menggunakan basis tunggal amilum dan F2 hanya menggunakan basis tunggal pati ampas tahu. Sedangkan F3, F4, dan F5 yang menggunakan variasi perbandingan basis amilum dan pati ampas tahu.

Hasil pengamatan warna secara visual menunjukkan bahwa semakin tinggi konsentrasi amilum maka sediaan pasta semakin berwarna kuning muda. Hal ini dikarenakan amilum berwarna putih sedangkan pasta berwarna kuning muda yang didapat dari warna piroksikam dan vaselin flavum. Sedangkan konsentrasi pati ampas tahu yang semakin tinggi menghasilkan sediaan pasta yang semakin berwarna putih kecoklatan. Pasta bewarna putih kecoklatan dikarenakan ampas tahu memiliki sifat fisik berwarna putih kecoklatan yang menutupi warna kuning dari piroksikam dan vaselin flavum.

Hasil uji sifat fisik berupa pengamatan bau pada semua formula pasta piroksikam sama yaitu berbau khas bahan corigen odoris escade. Hal ini menunjukkan bahwa tidak ada pengaruh konsentrasi ampas tahu terhadap bau pada sediaan pasta piroksikam yang dihasilkan. Hasil penyimpanan selama 28 hari pada suhu ruang menunjukkan formula pasta piroksikam stabil ditandai dengan tidak adanya perubahan bentuk, warna dan bau (Tabel 4).

Pengukuran pH. Nilai $\mathrm{pH}$ semua formula menunjukkan bahwa sediaan pasta piroksikam sesuai dengan rentang $\mathrm{pH}$ yang tidak mengiritasi kulit yaitu 4,5-6 sehingga aman digunakan ${ }^{(18)}$. Hasil ini menunjukkan bahwa tidak ada pengaruh konsentrasi pati ampas tahu dan lama penyimpanan terhadap pH sediaan pasta piroksikam. Berdasarkan hasil pengukuran $\mathrm{pH}$ (Tabel 5) diketahui bahwa semua formula sediaan pasta memiliki $\mathrm{pH}$ yang stabil yaitu 6 selama 28 hari penyimpanan pada suhu ruang.

Uji Viskositas. Hasil pengukuran viskositas sediaan pasta selama penyimpanan menunjukkan bahwa semua formula memenuhi rentang viskositas sediaan pasta (70.000-100.000 cps) dan relatif mengalami peningkatan setiap harinya (Gambar 5). Hal ini menunjukkan adanya pengaruh lama penyimpanan terhadap viskositas yaitu semakin lama penyimpanan menyebabkan peningkatan viskositas pada semua formula. Peningkatan viskositas pasta dapat terjadi karena sifat higroskopis amilum dan ampas tahu, dimana apabila didiamkan dalam waktu lama akan menjadi keras atau padat. Formula yang paling stabil adalah F3 dengan slope viskositas yang mendekati angka 0 dan nilai regresi mendekati 1 yaitu $\mathrm{b}=271,57$ dan $\mathrm{r} 2=0,89$ (Tabel 6).

Uji Daya Sebar. Hasil pengukuran uji daya sebar (Gambar 6) diketahui bahwa F3 adalah formula sediaan yang memiliki daya sebar paling baik yaitu antara 4,85-5,7 cm karena memiliki nilai daya sebar memasuki rentang $5-7 \mathrm{~cm}^{(19)}$. Hal ini menunjukkan bahwa F3 memiliki viskositas yang sesuai untuk menghasilkan daya sebar yang baik saat diaplikasikan pada kulit ${ }^{(20)}$. Hasil penelitian Astuti (2010) menunjukan semakin besar viskositas sediaan semakin besar tekanan yang diberikan agar sediaan tersebut dapat mengalir(21).

Uji Daya Lekat. Berdasarkan data hasil uji daya lekat yang diketahui bahwa semua formula memiliki daya lekat yang baik (Gambar 7) karena memiliki daya lekat lebih dari $1 \operatorname{detik}^{(22)}$. Uji daya lekat menunjukkan kemampuan pasta melekat dan melapisi permukaan kulit ketika digunakan agar dapat berfungsi maksimal ${ }^{(23)}$. Hasil uji daya lekat semua formula mengalami peningkatan pada saat penyimpanan.

Uji analisis statistik. Hasil analisis statistik (Tabel 7) menunjukkan bahwa data semua formula homogen dalam pengujian viskositas, daya sebar, maupun daya lekat karena didapat sig lebih dari 0,05. Hasil analisis menggunakan one way ANOVA didapat bahwa tidak terdapat perbedaan dalam data viskositas $(\mathrm{sig}=0,68)$ dan daya sebar $(\operatorname{sig}=0,51)$. Sedangkan pada data daya lekat $(\operatorname{sig}=0,03)$ menandakan bahwa adanya 
pengaruh pati ampas tahu berupa penurunan daya lekat sediaan. Hal ini menunjukkan bahwa pati ampas tahu dapat digunakan sebagai eksipien dalam sediaan pasta menggantikan eksipien zat pengikat amilum.

Uji Stabilitas. Hasil pengamatan uji stabilitas didapatkan semua formula tidak mengalami pemisahan 2 fase. Hasil ini didapatkan setelah

Tabel 4. Hasil uji organoleptik sediaan pasta piroksikam.

\begin{tabular}{|c|c|c|c|c|c|}
\hline \multirow{2}{*}{ Pengemantan } & \multicolumn{5}{|c|}{ Formla } \\
\hline & $\mathrm{FI}$ & $\mathrm{EL}$ & Fi & Ft & Ff \\
\hline$\overline{B a n}$ & Whas & Thas & Thass & Khas & Thas \\
\hline Thama & Kuning pudxa & Kerodilatinn & Puith wang & Putul thilng & Purtal thaldy \\
\hline Bentuk & Padet houngegen & Palat lomogonan & Paddit homogent & Padat houngegen & Padat bomogen \\
\hline
\end{tabular}

Tabel 4. Hasil uji pH sediaan pasta piroksikam.

\begin{tabular}{cc}
\hline Hari Ke- & $\mathrm{pH}$ \\
\hline 1 & 6 \\
3 & 6 \\
5 & 6 \\
7 & 6 \\
14 & 6 \\
21 & 6 \\
28 & 6 \\
\hline
\end{tabular}

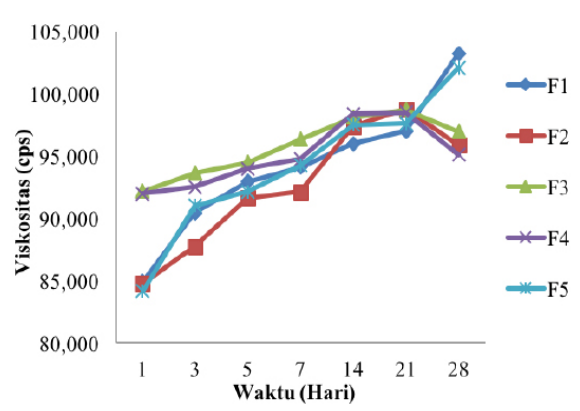

Gambar 5. Hasil uji viskositas sediaan pasta piroksikam.

Tabel 6. Data slope viskositas.

\begin{tabular}{|c|c|c|c|}
\hline \multirow{2}{*}{ No } & \multirow{2}{*}{ Formula } & \multicolumn{2}{|c|}{ Viskositas } \\
\hline & & Slope & $R^{2}$ \\
\hline 1 & Fl (Amilum : Ampas Tahu = 2,5:0) & 512,96 & 0,83 \\
\hline 2 & F2 (Amilum : Ampas Tahu = $0: 2,5)$ & 418,02 & 0,68 \\
\hline 3 & F3 (Amilum : Ampas Tahu = 1,25: 1,25) & 271,57 & 0,89 \\
\hline 4 & F4 (Amilum : Ampas Tahu = $1: 1,5)$ & 169,69 & 0,44 \\
\hline 5 & F5 (Amilum: Ampas Tahu = 1,5:1) & 514,54 & 0,81 \\
\hline
\end{tabular}

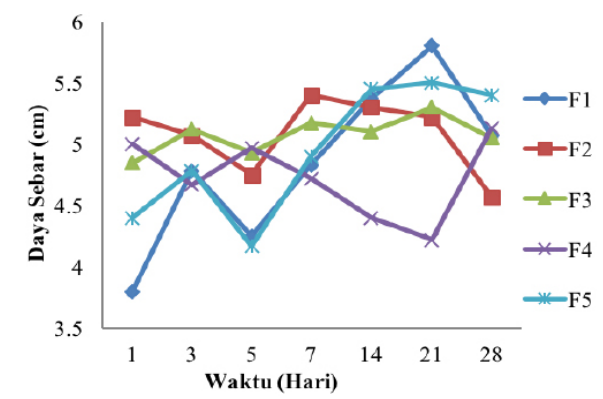

Gambar 6. Hasil uji daya sebar sediaan pasta piroksikam.

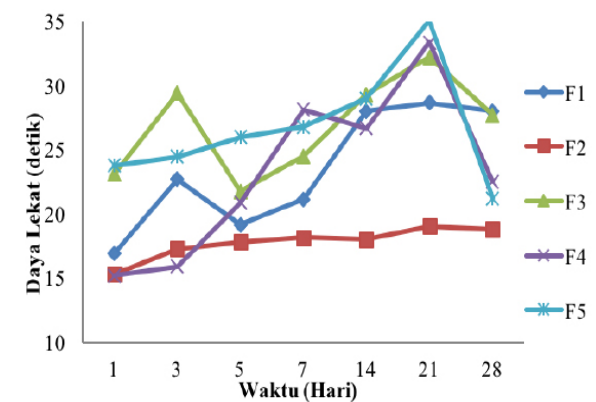

Gambar 7. Hasil uji daya lekat sediaan pasta piroksikam.

Tabel 7. Data signifikansi analisis statistik.

\begin{tabular}{|c|c|c|c|}
\hline \multirow{2}{*}{ No } & \multirow{2}{*}{ Analissis Hasil Evaluasi } & \multicolumn{2}{|c|}{ Signifikansi } \\
\hline & & Homogenitas & One Hav ANOPA: \\
\hline 1 & Viskositas & 0,385 & 0,680 \\
\hline 2 & Dayn Sebar & 0,191 & 0,516 \\
\hline 3 & Daya Lekat & 0,310 & 0,030 \\
\hline
\end{tabular}

dilakukan 6 sikuls perlakuan selama 24 hari yaitu setelah penyimpanan dalam suhu dingin $\left(4^{\circ} \mathrm{C}\right)$ selama 48 jam yang dilanjutkan penyimpanan dalam suhu oven $\left(40^{\circ} \mathrm{C}\right)$ selama 48 jam dan diulangi sebanyak 6 kali $^{(24)}$. Dapat disimpulkan bahwa sediaan pasta piroksikam baik yang menggunakan amilum dan atau pati ampas tahu memiliki kestabilan yang baik dalam penyimpanan $^{(25)}$.

\section{SIMPULAN}

Formula optimum pasta piroksikam berbasis ampas tahu yaitu F3 dengan perbandingan serbuk amilum dan ampas tahu 1,25:1,25.

\section{DAFTAR PUSTAKA}

1. Kementerian Kesehatan Republik Indonesia. Peraturan Menteri Kesehatan No. 87 Tahun 2013 Tentang Peta Jalan Pengembangan Bahan Baku Obat. Kementerian Kesehatan Republik Indonesia; 2013.

2. Rowe RC, Sheskey PJ, Quinn ME. Handbook of pharmaceutical excipients. $6^{\text {th }}$ ed. USA: Pharmaceutical Press and American Pharmacists Association; 2009.

3. Tifani AM, Kumalaningsih S, Mulyadi AF, Pertanian AJTI, Pertanian SPJTI. Produksi bahan pakan ternak dari ampas tahu dengan fermentasi menggunakan EM4 (Kajian $\mathrm{pH}$ awal dan lama waktu fermentasi). J Ilm Peternak. 2010. 5(1):78-88.

4. Mufrod, Sundari S. Waste of soya tofu as paracetamol tablet desintegrant. Pharm J. 1997. 1:17.

5. Fressia YM. Pengujian ampas tahu kering dibandingkan Avicel PH 101 sebagai disintegran tablet parasetamol yang dibuat secara granulasi basah. Universitas Surabaya; 2000.

6. Utami DF. Uji kelayakan ampas tahu kering sebagai disintegran tablet vitamin $\mathrm{C}$ yang dibuat secara cetak langsung dibandingkan dengan Avicel PH 101. 
Universitas Surabaya; 2000.

7. Agoes G. Sediaan farmasi likuida-semisolida. Bandung: ITB; 2012.

8. Medscape. Piroxicam. 2016 Oktober; Available from: http://reference.medscape.com/drug/feldenepiroxicam-343300

9. Ansel HC, Allen LVA, Popovich NG. Pharmaceutical dosage forms and drug delivery system. Philadelphia: Lippincott Williams and Wilkins; 1999.

10. Jufri M, Anwar E, Utami PM. Uji stabilitas sediaan mikroemulsi menggunakan hidrolisat pati (De 35-40) sebagai stabilizer. Pharm Sci Res PSR. 2012. 3(1).

11. Lachman L, Lieberman HA, Kanig JL. Teori dan praktek farmasi indrustri. $3^{\text {rd }}$ ed. New York: Marcel Dekker, Inc.; 1998. (2). 265-7, 272-3.

12. Nayeem N, Md K. Stability studies and evaluation of the semi solid dosage form of the rutin, quercitin, ellagic acid, gallic acid and sitosterol isolated from the leaves of Tectona grandis for wound healing activity. Arch Appl Sci Res. 2011. 3(1):43-51.

13. Aswal A, Kalra M, Rout A. Preparation and evaluation of polyherbal cosmetic cream. Pharm Lett. 2013. 5(1):83-8.

14. Kemenkes RI. Farmakope Indonesia. $5^{\text {th }}$ ed. Jakarta: Kementerian Kesehatan Republik Indonesia; 2014.

15. Junaedi. Preparasi dan karakterisasi eksipien koproses karagenan (Kappa dan lota) dengan pregelatinasi pati singkong propionat sebagai eksipien dalam sediaan tablet mengapung famotidin. Universitas Indonesia; 2012.

16. Whistler RL, BeMiller JN. Industrial gum: polysaccharides and their derivates. New York: Academic Press; 1993.

17. Lachman L, Lieberman HA, Kanig L. Teori dan praktek farmasi industri. Jakarta: Universitas Indonesia Press; 1994.

18. Tranggono IR, Latifah. Buku pegangan ilmu pengetahuan kosmetika. Jakarta: PT. Gramedia Pustaka Utama; 2007.

19. Garg A, Aggarwal D, Garg S, Singla AK. Spreading of semisolid formulation. Pharmaceutical Tecnology. 2002. 9(2):84-102.

20. Mappa T, Edy HJ, Kojong N. Formulasi gel ekstrak daun sasaladahan (Peperomia pellucida (L.) H.B.K) dan uji efektivitasnya terhadap luka bakar pada kelinci (Oryctolagus Cuniculus). Pharmacon. 2013. 2(2).

21. Astuti lka Y, Hartanti D, Aminiati A. Peningkatan aktivitas antijamur Candida albicans salep minyak atsiri daun sirih (Piper Bettle Linn.) melalui pembentukan kompleks inklusi dengan B-siklodekstrin - enhancing antifungal activity Candida. Maj Obat Tradis. 2010. 15.

22. Lieberman AH, Rieger MM, Banker SG. Pharmaceutical dosage forms: disperse system. $2^{\text {nd }}$ ed. Vol. 3. New York: Marcel Dekker, Inc; 1998. 265-7, 272-3.

23. Voigt R. Buku pelajaran teknologi farmasi. Yogyakarta: UGM Press; 1995.

24. Madjid S, Naser DM, Djavad F. Prevention of crystal growth in Acetaminophen suspension by the use of polyvinyl pyrrolidone and bovine serum albumin. International Journal of Pharmacy and Pharmaceutics Sciences. 2003. 11(3):139-48.

25. Jusnita J, Syah RA. Formulasi dan uji stabilitas fisik sediaan shampo dari ekstrak etanol daun pare (Momordica charantia Linn.). Indonesia Natural Research Pharmaceutical Journal. 2017. 2(1):24-39. 